\title{
Low-molecular-weight heparin and prevention of postoperative deep vein thrombosis
}

\author{
V V KAKKAR, B DJAZAERI, J FOK, M FLETCHER, M F SCULLY, J WESTWICK
}

\begin{abstract}
The efficacy of low-molecular-weight heparin as a prophylactic agent was assessed in 150 consecutive patients over the age of 40 undergoing major abdominal surgery. Fifty of these patients received 1250 activated partial thromboplastin time (APTT) units of lowmolecular-weight heparin every 12 hours: three developed isotopic deep vein thrombosis, which was confirmed by phlebography in two cases. The other 100 patients received a single injection of 1850 APTT units of lowmolecular-weight heparin. Three of them developed isotopic deep vein thrombosis; phlebography failed to confirm the presence of thrombi in each case. None of the 150 patients studied died from fatal or contributory pulmonary emboli. Low-molecular-weight heparin was not associated with any increase in preoperative or postoperative bleeding. The effect of equal amounts of low-molecular-weight heparin and unfractionated heparin on the coagulation mechanism during surgery was investigated in another 30 patients. The clotting assays and results of in-vivo platelet function tests indicated that both preparations produced similar effect. Intragroup comparisons, however, showed significant differences in the anti-factor $\mathrm{Xa}$ activity, lipoprotein lipase release, and plasma prekallikrein concentrations.

A single injection of low-molecular-weight heparin daily is a convenient way of preventing deep vein thrombosis in high-risk patients undergoing major abdominal surgery.
\end{abstract}

\section{Introduction}

The anticoagulant action of heparin results from its ability to bind and activate antithrombin III, a heparin cofactor. Antithrombin III inhibits several activated coagulation factors in addition to thrombin, including factors IXa, Xa, XIa, and XIIa; all these inhibition reactions are greatly accelerated in the presence of heparin. ${ }^{1-5}$ Commercially available heparin consists of components with molecular weights ranging from 3000 to 40000 daltons and an average of about 15000.6 ? Studies on heparin fractions of different molecular weights obtained by gel filtration have shown a molecular-size-dependency of the anticoagulant activity. ${ }^{8-12}$ The potentiation of the inhibition of factor $\mathrm{Xa}$ in plasma system increases with decreasing molecular weight. $^{8-10}$ In contrast, measurements by multiple-role clotting assay such as the activated partial thromboplastin time (APTT) decrease with decreasing molecular weight. ${ }^{10-13}$

We investigated whether low-molecular-weight and unfractionated heparin affect the coagulation mechanism to the same extent in patients undergoing major abdominal surgery, and whether low-molecular-weight heparin prevents postoperative deep vein thrombosis without producing excessive bleeding.

\section{Patients and methods}

One hundred and eighty patients undergoing major abdominal surgery were investigated. All received a written and oral description of the study protocol and gave their consent to participate.

Heparin-Unfractionated heparin was commercial heparin calcium (Calciparine); to prepare low-molecular-weight fraction, it was extracted with a mixture of ethanol and water ${ }^{14}$ and purified. The fraction was studied by physical $\left({ }^{13} \mathrm{C}\right.$-nuclear magnetic resonance spectroscopy) and chemical techniques. Compared with unfractionated heparin, the low-molecular-weight fraction contained a higher percentage of non-sulphated uronic acid-particularly glucuronic acid (about $30 \%$ to total uronic acids) - as well as a higher percentage of $\mathrm{N}$-acetyl-glucosamine, whereas the content in sulphate groups was lower (J Choay, personal communication). The molecular weights of unfractionated heparin and the low-molecular-weight fraction were estimated by comparing their elution positions from a column of Ultrogel with the fractions whose molecular weights had been determined by a sedimentation diffusion equilibrium method. The mean molecular weight of unfractionated heparin was 16000 daltons and of low-molecular-weight heparin 6000 daltons. The anticoagulant

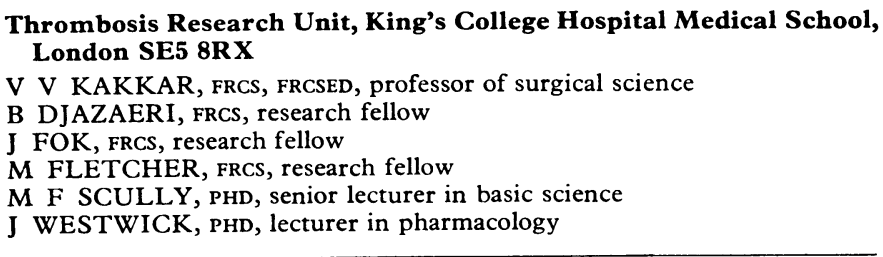


activities of the two heparin preparations were assessed using APTT ${ }^{15}$ and anti-factor $\mathrm{Xa}$ clotting assays. ${ }^{16}$ The low-molecular-weight fraction had a specific activity of $200 \mathrm{U} / \mathrm{mg}$ in anti-factor Xa assay and $50 \mathrm{U} / \mathrm{mg}$ in APTT assay. The ratio between both types of activities in tests using human plasma was thus 4 . Unfractionated heparin had a specific activity of $150 \mathrm{U} / \mathrm{mg}$ in both assays. The low-molecularweight fraction was supplied in a single-dose phial prepared under approved pharmaceutical conditions and containing either 1250 APTT units (5000 anti-factor Xa units) in $0.2 \mathrm{ml}$ or 1850 APTT units $(7500$ anti-Xa units) in $0.3 \mathrm{ml}$. Results of tests for sterility and pyrogens were satisfactory.

Effect on coagulation mechanism-Thirty patients were allocated at random to receive 5000 anti-factor Xa units of low-molecular-weight or unfractionated heparin subcutaneously, starting two hours before surgery and then every 12 hours for seven days afterwards. Blood samples were obtained before administration of heparin, before surgery in the anaesthetic room, midway during operation, in the recovery room, and on the first and seventh postoperative days. They were analysed for heparin concentrations measured by anti-factor Xa assay, antithrombin III concentration, lipoprotein lipase release, $\underline{\underline{T}}$ APTT, plasma fibrinopeptide $\mathrm{A}$, and prekallikrein concentrations, 3 and for in-vivo platelet function by estimating the concentration of $\beta$-thromboglobulin, platelet factor 4 , and thromboxane $B_{2}$ formation. $C$ In another 25 patients, who received 1850 APTT units of lowmolecular-weight heparin daily, Simplate bleeding time was measured before, during, and 24 hours after surgery. Blood samples were takenp at the same time for estimation of heparin concentration.

Prevention of deep vein thrombosis-The efficacy of low-molecular weight heparin in preventing postoperative deep vein thrombosis was? assessed in 150 consecutive patients. Tables I and II give the details: of age, sex, type of operation performed, and other risk factors likelyos to influence the incidence of deep vein thrombosis. The first 500 patients (23 men, 27 women) received 1250 APTT units of lowmolecular-weight heparin subcutaneously starting two hours before surgery and repeated every 12 hours thereafter for seven days. The other 100 patients ( 39 men, 61 women) received a single daily injection of 1850 APTT units of low-molecular-weight heparin starting two v hours before surgery and continuing for seven days after operation.
TABLE I-Details of 150 patients receiving injections of low-molecular-weight heparin

\begin{tabular}{|c|c|c|c|c|c|c|c|}
\hline & & & & & & $\begin{array}{c}\text { No given } \\
\text { two injections } \\
\text { daily } \\
(n=50)\end{array}$ & $\begin{array}{c}\text { No given } \\
\text { one injection } \\
\text { daily } \\
(\mathbf{n}=100)\end{array}$ \\
\hline \multicolumn{8}{|c|}{ Age of patients (years): } \\
\hline $40 \quad \cdots$ & . & . & . & . & . & 2 & \\
\hline $40-49$ & .. & . & .. & . & $\therefore$ & 9 & 19 \\
\hline $50-59$ & . & . & .. & $\therefore$ & $\therefore$ & 11 & 23 \\
\hline $60-69$ & .. & $\therefore$ & $\therefore$ & $\therefore$ & $\because$ & 18 & 30 \\
\hline 70 & . & . & . & . & . & 10 & 24 \\
\hline \multirow{2}{*}{\multicolumn{8}{|c|}{ Predisposing risk factors: }} \\
\hline & & & & & & & \\
\hline Varicose veins & .. & & & & . & 6 & 11 \\
\hline Varicose ulcer & $\therefore$ & $\therefore$ & $\therefore$ & 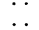 & $\therefore$ & 1 & 7 \\
\hline \multirow{2}{*}{\multicolumn{8}{|c|}{ Previous deep vein thrombosis with or without }} \\
\hline & & & & & & & \\
\hline \multirow{2}{*}{\multicolumn{3}{|c|}{$\begin{array}{l}\text { pulmonary embolism } . \\
\text { Previous myocardial infarction }\end{array}$}} & .. & . & & 2 & 3 \\
\hline & & & $\ldots$ & $\therefore$ & $\ldots$ & 2 & 5 \\
\hline \multirow{2}{*}{\multicolumn{2}{|c|}{$\begin{array}{l}\text { Chronic bronchitis } \\
\text { Oestrogen treatment }\end{array}$}} & & . & 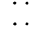 & $\because$ & 3 & 4 \\
\hline & & $\because$ & $\because$ & 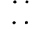 & 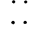 & & 5 \\
\hline
\end{tabular}

TABLE II-Operations performed on 150 patients receiving injections of lowmolecular-weight heparin

\begin{tabular}{|c|c|c|c|c|c|c|}
\hline & & & & & $\begin{array}{l}\text { No of patients } \\
\text { receiving } \\
\text { two injections } \\
\text { daily } \\
(\mathrm{n}=50)\end{array}$ & $\begin{array}{l}\text { No of patients } \\
\text { receiving } \\
\text { one injection } \\
\text { daily } \\
(n=100)\end{array}$ \\
\hline \multicolumn{2}{|l|}{ Gastric } & . & .. & . & 15 & 21 \\
\hline \multirow{2}{*}{\multicolumn{2}{|c|}{$\begin{array}{l}\text { Oesophagectomy } \ldots \\
\text { Total and partial gastrectomy }\end{array}$}} & .. & .. & . & & \\
\hline & & .. & .. & . & 4 & 10 \\
\hline \multicolumn{2}{|c|}{ Vagotomy and pyloroplasty } & . & .. & . & 6 & 6 \\
\hline \multicolumn{2}{|l|}{ Gastroenterostomy } & $\therefore$ & .. & . & 4 & \\
\hline \multicolumn{2}{|c|}{ Biliary $\quad \ldots \quad$.. $\quad}$. & . & .. & $\cdots$ & 16 & 31 \\
\hline \multirow{2}{*}{\multicolumn{7}{|c|}{$\begin{array}{l}\text { Cholecystectomy alone } \\
\text { Cholecystectomy and exploration of common }\end{array}$}} \\
\hline & & & & & & \\
\hline bile duct ... & .. & . & .. & . & 3 & 5 \\
\hline \multirow{2}{*}{\multicolumn{3}{|c|}{ Cholecystoenterostomy $\ddot{\text { Prainage }}$}} & .. & $\therefore$ & 1 & 2 \\
\hline & & & . & 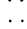 & & 3 \\
\hline \multicolumn{2}{|c|}{ Large bowel .. } & .. & . & & 16 & 27 \\
\hline & . & .. & & 7 & 9 \\
\hline \multicolumn{2}{|l|}{$\begin{array}{l}\text { Total and partial colectomy } \\
\text { Anterior resection .. }\end{array}$} & . & .. & . . & 4 & 6 \\
\hline \multirow{2}{*}{\multicolumn{2}{|c|}{ Anteroposterior resection .. }} & $\ldots$ & $\therefore$ & $\therefore$ & 3 & 4 \\
\hline & & $\therefore$ & $\therefore$ & $\cdots$ & 2 & 8 \\
\hline \multicolumn{2}{|l|}{$\begin{array}{l}\text { Closure of colostomy } \\
\text { Miscellaneous }\end{array}$} & $\therefore$ & $\ldots$ & . & 3 & 21 \\
\hline \multirow{2}{*}{$\begin{array}{l}\text { Hysterectomy } \\
\text { Laparotomy and biopsy }\end{array}$} & $\therefore$ & . & . & & & 7 \\
\hline & . & . & . & & 1 & 6 \\
\hline Mastectomy & $\therefore$ & $\therefore$ & $\ldots$ & . & 2 & 5 \\
\hline Nephrectomy & . & . & . & $\cdots$ & & 3 \\
\hline
\end{tabular}

\section{ASSESSMENT}

Deep vein thrombosis was detected by the radioactive fibrinogen uptake test using the technique previously described. ${ }^{17}$ Patients were scanned for at least 10 days and deep vein thrombosis was diagnosed if the counts at any site differed by $20 \%$ or more from those at the adjacent points on the same leg or at the same position in the opposite leg and if this difference persisted or increased in the subsequent $24 \omega$ hours. In patients who had raised counts ascending phlebograms werevr obtained to determine the exact site and extent of the thrombus. ${ }^{18}$ 을

Blood loss-The surgeon assessed blood loss during operation as excessive or not. Surgical wounds and heparin injection sites were examined every day for haematoma formation. The haemoglobin $\mathbb{D}$ value before and a week after surgery and blood transfusion requirements were also noted.

Laboratory tests-Venous blood for haematological tests was collected in trisodium citrate $(3.8 \%)$ solution at a ratio of one part citrate to nine parts blood. Blood for measurement of fibrinopeptide A was collected in $0.5 \mathrm{ml}$ of an anticoagulant mixture containing 500 $\mathrm{U}$ of aprotinin (Trasylol) and $0.5 \mathrm{mmol}$ epsilon aminocaproic acid.o The first $2 \mathrm{ml}$ of blood after a venepuncture was discarded and the next $4.5 \mathrm{ml}$ collected into $0.5 \mathrm{ml}$ of the anticoagulant mixture. $\overline{\mathrm{O}}$ Platelet-poor plasma was prepared by centrifugation at $3000 \mathrm{~g}$ for 30 ڤึ minutes at $4{ }^{\circ} \mathrm{C}$ and stored at $-20^{\circ} \mathrm{C}$ until assayed. Chromogenic assays were used for measuring heparin concentrations using substrate $\overrightarrow{\vec{f}}$ S2222, and for determining antithrombin III concentrations using substrate S2238. The details of the techniques of those assays have been described. ${ }^{19}$ The standard curves were prepared using a normal pool of plasma with the Third International Heparin Standard:(National Institute for Biological Standards and Control, Holly Hill, London). APTT was measured on platelet-poor plasma samples within one hour of blood collection using techniques described by:Hardisty and Ingram. ${ }^{20}$ Assays of lipoprotein lipase activity were carried out by the method of Nilsson-Ehle and Schotz. ${ }^{21}$ Plasma prekallikrein concentrations were measured using the method of Kluft ${ }^{22}$ and fibrinopeptide A concentrations by the method of Kockum
and Frebeluis. ${ }^{23}$

Platelet function tests-A 5-ml sample of blood was collected with N a $19-\mathrm{G}$ bore needle using clean venepuncture without stasis, and one- $\sigma$ half volume aliquots were placed in ice tubes containing edetic acid $\frac{D}{0}$ and theophylline and the other half in similar tubes containing edetic acid theophylline, and freshly prepared indomethacin $55 \mathrm{mmol}(2 \mathrm{~N}$ $\mathrm{mg} / 100 \mathrm{ml}$ ) to reduce artefactual production of thromboxane $\mathbf{B}_{\mathbf{2}} \cdot \mathrm{N}$ These tubes were kept in ice and centrifuged within 30 minutes at

TABLE III-Effect of low-molecular-weight and unfractionated heparin on clotting assays. Results are means $\pm S E M$

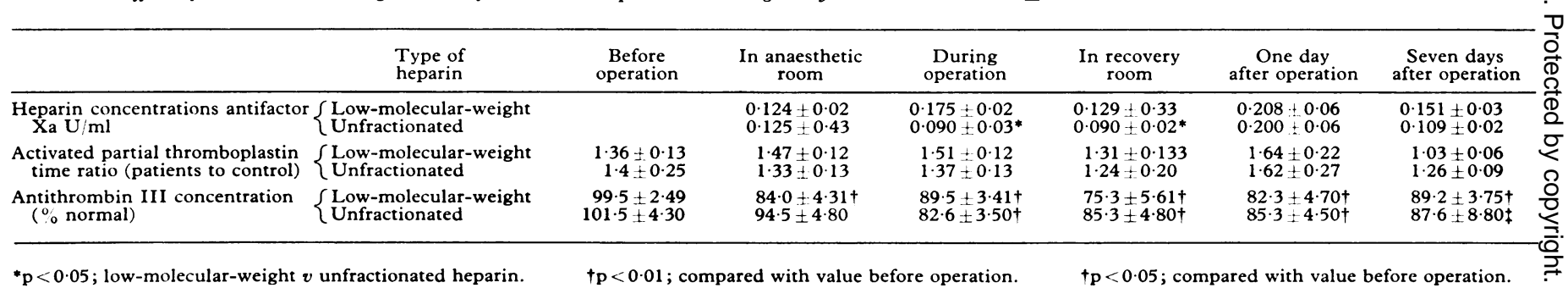


TABLE IV-Effect of low-molecular-weight and unfractionated heparin on coagulation assays. Results are means it SEM

\begin{tabular}{|c|c|c|c|c|c|c|c|}
\hline & $\begin{array}{l}\text { Type of } \\
\text { heparin }\end{array}$ & $\begin{array}{l}\text { Before } \\
\text { operation }\end{array}$ & $\begin{array}{l}\text { In anaesthetic } \\
\text { room }\end{array}$ & $\begin{array}{c}\text { During } \\
\text { operation }\end{array}$ & $\begin{array}{l}\text { In recovery } \\
\text { room }\end{array}$ & $\begin{array}{l}\text { One day } \\
\text { after operation }\end{array}$ & $\begin{array}{l}\text { Seven days } \\
\text { after operation }\end{array}$ \\
\hline Prekallikrein (", normal) & $\left\{\begin{array}{l}\text { Low-molecular-weight } \\
\text { Unfractionated }\end{array}\right.$ & $\begin{array}{l}67 \cdot 8: 8 \cdot 90 \\
64 \cdot 3: 6 \cdot 20\end{array}$ & $\begin{array}{l}71 \cdot 8+8 \cdot 90 \\
60 \cdot 5 \div 5 \cdot 60\end{array}$ & $\begin{array}{l}66 \cdot 6: 8 \cdot 20 \\
61 \cdot 5: 5 \cdot 70\end{array}$ & $\begin{array}{l:l}64.9 & 12 \cdot 20 \\
64 \cdot 8 & 6 \cdot 80\end{array}$ & $\begin{array}{l}62 \cdot 1 \pm 12 \cdot 2 \\
37 \cdot 4 \pm 8 \cdot 30^{*}\end{array}$ & $\begin{array}{l}48 \cdot 6 \pm 9 \cdot 00 \\
32 \cdot 0 \pm 4 \cdot 60 \dagger\end{array}$ \\
\hline Lipoprotein lipase release ( $\mathrm{mU} 1)$ & $\left\{\begin{array}{l}\text { Low-molecular-weight } \\
\text { Unfractionated }\end{array}\right.$ & 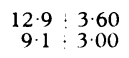 & $\begin{array}{l:l}25 \cdot 7 & 3.90^{\dagger} \\
45 \cdot 0 & 9 \cdot 40 \$+\end{array}$ & $\begin{array}{l:l}21 \cdot 1 & 4 \cdot 00^{\dagger} \\
33 \cdot 3 & 10 \cdot 20^{\dagger}\end{array}$ & $\begin{array}{r}26 \cdot 14: 5 \cdot 00^{\dagger} \\
35 \cdot 2 \div 7 \cdot 10^{\dagger}\end{array}$ & $\begin{array}{l}24 \cdot 8 \pm 6 \cdot 50 \dagger \\
22 \cdot 5 \pm 5 \cdot 30 \dagger\end{array}$ & $\begin{array}{l}16 \cdot 5 \pm 4 \cdot 10 \\
20 \cdot 5 \pm 7 \cdot 50+\end{array}$ \\
\hline Fibrinopeptide 4 (ng l) & $\left\{\begin{array}{l}\text { Low-molecular-weight } \\
\text { Unfractionated }\end{array}\right.$ & $\begin{array}{r:l}1.5 & 0.42 \\
1.48 & 0.29\end{array}$ & $\begin{array}{rl}1.8 & 0.46 \\
2.56 & 0.45\end{array}$ & $\begin{array}{r:l}3.55 & 0.55+ \\
3.7 & 0.39+\end{array}$ & $\begin{array}{r}2.9 \\
3.09 \\
0.470^{*}\end{array}$ & $\begin{array}{l}2 \cdot 55 \div 0.63 \ddagger \\
2 \cdot 16 \neq 0.62\end{array}$ & $\begin{array}{l}2 \cdot 2 \pm 0 \cdot 44 \\
2 \cdot 5 \pm 5 \cdot 30\end{array}$ \\
\hline
\end{tabular}

* p 0.01 ; compared with value before operation.

$\neq p$. 0.05; compared with value before operation.

+ p. 0.001 ; compared with value before operation.

$\$ p$. 0.05 ; low-molecular-weight $v$ unfractionated heparin.

TABLE V-Effect of low-molecular-weight and unfractionated heparin on in-vivo platelet function. Results expressed as median (range in parentheses)

\begin{tabular}{|c|c|c|c|c|c|c|c|}
\hline & $\begin{array}{l}\text { Type of } \\
\text { heparin }\end{array}$ & $\begin{array}{c}\text { Before } \\
\text { operation }\end{array}$ & $\begin{array}{l}\text { In anaesthetic } \\
\text { room }\end{array}$ & $\begin{array}{c}\text { During } \\
\text { operation }\end{array}$ & $\begin{array}{l}\text { In recovery } \\
\text { room }\end{array}$ & $\begin{array}{l}\text { One day } \\
\text { after operation }\end{array}$ & $\begin{array}{l}\text { Seven days } \\
\text { after operation }\end{array}$ \\
\hline S-Thromboglobulin ( $\lfloor\mathrm{g} \mathrm{I}$ ) & $\left\{\begin{array}{l}\text { Low-molecular-wcight } \\
\text { Unfractionated }\end{array}\right.$ & $\begin{array}{l}63(42-80) \\
57(28-84)\end{array}$ & $\begin{array}{l}53(38-69) \\
52(27-56)\end{array}$ & $\begin{array}{l}72(29-182) \\
74(49-148)\end{array}$ & $\begin{array}{r}50.5(36-129) \\
80(39-122)\end{array}$ & $\begin{array}{l}51(30-74) \\
35(26-54)\end{array}$ & $\begin{array}{l}43(34-48) \\
40(32-57)\end{array}$ \\
\hline Plasma factor $4(\mu \mathrm{g} \mathrm{l})$ & $\left\{\begin{array}{l}\text { Low-molecular-weight } \\
\text { Unfractionated }\end{array}\right.$ & $\begin{array}{l}18(12-32) \\
26(13-32)\end{array}$ & $\begin{array}{l}17(13.23) \\
29(23-31)\end{array}$ & $\begin{array}{l}16(8-20) \\
36(20-39)\end{array}$ & $\begin{array}{l}20(18-28) \\
40(13-53)\end{array}$ & $\begin{array}{l}18(16-20) \\
20(16-23)\end{array}$ & $\begin{array}{l}22(12-21) \\
21(14-31)\end{array}$ \\
\hline Thromboxane B (ng/l) & $\left\{\begin{array}{l}\text { Low-molecular-weight } \\
\text { Unfractionated }\end{array}\right.$ & $\begin{array}{r}90(40-120) \\
110(30-160)\end{array}$ & $\begin{array}{l}140(120-160) \\
150(80-350)\end{array}$ & $\begin{array}{l}190 *(130-280) \\
300+(180-790)\end{array}$ & $\begin{array}{l}160 *(110-260) \\
250+(160-600)\end{array}$ & $\begin{array}{l}130(60-180) \\
200(100-390)\end{array}$ & $\begin{array}{r}80(50-200) \\
180(90-400)\end{array}$ \\
\hline
\end{tabular}

* $\mathrm{p}$. 0.05; compared with value before operation.

tp 0.02 ; compared with value before operation.

$2300 \mathrm{~g}$ for 30 minutes at $4 \mathrm{C}$ to produce platelet-poor plasma. Plasma was removed and stored at $-20 \mathrm{C}$. Plasma concentrations of 3 thromboglobulin and platelet factor 4 were measured using a radioimmunoassay kit (Radiochemical Centre, Amersham, and Abbott Laboratories, Queenborough, Kent). Concentration of thromboxane $\mathrm{B}_{2}$ was measured by the techniques of Levy et al. ${ }^{24}$

Simplate bleeding time was determined by the method of Mielke et al. ${ }^{26}$ The Simplate is a spring-loaded device that produces a guillotine-like incision of constant length and depth. A blood-pressure cuff was applied to the upper arm and then inflated to $40 \mathrm{~mm} \mathrm{Hg}$; after waiting 30 seconds to allow uniform capillary filling, the Simplate was placed on the skin with the slot running parallel to the elbow crease. A circular filter paper blotted the drops of blood every 30 seconds. The end-point was reached when the blood no longer stained the filter paper.

Statistical analysis-An analysis of variance was performed on the data obtained after subcutaneous and intravenous injection of the lowmolecular-weight and unfractionated heparin using a Commodore S61 preprogrammed statistical calculator. A significant difference was determined by the Student $t$ test for paired values. Whenever the variables were not normally distributed, the non-parametric statistics in the form of a Mann Whitney two-tail test was used to analyse the data.

\section{Results}

Effect on coagulation mechanism-Tables III, IV, and V show the results of clotting assays and platelet function tests after subcutaneous administration of heparin.

APTT and heparin and antithrombin III concentrations (table III)There was no significant difference in the mean APTT after administration of two preparations of heparin in the samples withdrawn in the anaesthetic room, during surgery, in the recovery room, and on the first and seventh postoperative days. Heparin concentrations measured by an anti-factor Xa assay showed a different response in the two groups; the mean concentration in the sample withdrawn during surgery was $0 \cdot 175+S E M \quad 0.02 \mathrm{U} / \mathrm{ml}$ in the group who received low-molecular-weight heparin and $0.09 \pm 0.03 \mathrm{U} / \mathrm{ml}$ in the group receiving unfractionated heparin; this difference was statistically significant $(p<0.05)$. The mean concentration of antithrombin III before surgery was $99.5 \%$ of the normal in the patients who received low-molecular-weight heparin; a significant fall was observed during and after surgery. Similar changes were also seen in patients who received unfractionated heparin.

Prekallikrein, lipoprotein lipase, and fibrinopeptide $A$ (table IV)-A significant difference in plasma prekallikrein concentration was observed on the first and seventh postoperative days compared with the preoperative value in the patients who received unfractionated heparin; the preoperative value was $64.3 \pm$ SEM $6.2 \%$ of the normal and this fell to $37 \cdot 4 \pm 8.3 \%$ on the first and $32.0 \pm 4.6 \%$ on the seventh postoperative days $(\mathrm{p}<0 \cdot 01)$. The plasma prekallikrein concentration remained raised throughout the observation period in the group receiving low-molecular-weight heparin (table IV). Both lowmolecular-weight and unfractionated heparin caused a significant increase in lipoprotein lipase activity, the raised activities subsequently persisted throughout the period of observation (table IV). The increase was even greater in those who received unfractionated heparin. The difference in the lipoprotein lipase release in the two groups was statistically significant $(\mathrm{p}<0.05)$. A significant increase in the concentrations of fibrinopeptide $\mathrm{A}$ was also observed during and after surgery in both groups, but the difference between the two groups was not significant (table IV).

3-thromboglobulin, platelet factor 4 , thromboxane $B_{2}$ concentrations, and bleeding time (table V)-As the results of platelet-function tests were not normally distributed non-parametric statistics in the form of a Mann-Whitney two-tail test was used to analyse the data obtained. An increase in the concentrations of $\beta$-thromboglobulin and platelet factor 4 was observed during surgery in both groups, but the differences, when compared with the preoperative values or intragroup values, were not significant. In the group receiving unfractionated heparin the median concentrations of thromboxane $B_{2}$ increased from $110 \mathrm{ng} / \mathrm{l}$ before surgery to $300 \mathrm{ng} / \mathrm{l}$ during operation, this difference being statistically significant $(p<0 \cdot 02)$. Raised concentrations were also observed in the samples withdrawn in the recovery room. Figure 1 shows Simplate bleeding time in 25 patients who received a single injection of 1850 APTT units of low-molecular-weight heparin. The difference between the mean Simplate bleeding time before, during, and 24 hours after surgery was not statistically significant, though a rise greater than $1 \mathrm{SD}$ was observed in six patients. In seven patients the bleeding time was reduced to below $1 \mathrm{SD}$, five of these being operated on for malignant disease. The mean plasma heparin concentration during surgery was $0.28 \mathrm{U} / \mathrm{ml}$, the range being 0.08 to 0.6 $\mathrm{U} / \mathrm{ml}$. Increases in the Simplate bleeding time were unrelated to changes in the plasma heparin concentration. In nine of 25 patients, circulating heparin could still be detected 24 hours after a single subcutaneous injection (fig 2).

Prevention of deep vein thrombosis-Of 150 consecutive patients investigated, the first 50 received 1250 APTT units of the lowmolecular-weight heparin every 12 hours while the other 100 patients received a single injection of 1850 APTT units of low-molecularweight heparin daily during the first seven days after operation. Isotopic deep vein thrombosis was diagnosed in three of the 50 patients receiving two injections daily; phlebography confirmed the presence of thrombi in only two cases, and in each instance, thrombi were confined to calf veins only. Thrombi were detected on the seventh, 11 th, and 15 th postoperative days. Twelve out of 50 patients were operated on for malignant disease, and none of these developed deep vein thrombosis. None of these patients developed symptoms or signs of minor pulmonary embolism, and none died during the postoperative period. Isotopic deep vein thrombosis was detected in three of 100 patients receiving one injection of low-molecular-weight 
heparin daily. Thrombi were detected on the second, fourth, and sixth postoperative days and the raised counts persisted for $\mathbf{4 8}$ to 72 hours only. Phlebography failed to confirm the presence of thrombi in each instance. Three patients died during the postoperative period and necropsy was performed in each case: one patient died on the ninth postoperative day owing to Gram-negative septicaemia after the resection of carcinoma of the sigmoid colon; the other two patients died from advanced carcinomatosis secondary to carcinoma of stomach, one on the 14th and the other on the 19th day after operation. Both patients had palliative gastrojejenostomy. No pulmonary emboli or thrombi in the deep veins were found at necropsy.

Operative and postoperative bleeding-Prophylaxis was discontinued in two patients who received low-molecular-weight heparin every 12 hours; one developed extensive bruising at the site of injection and the other had excessive blood loss at the time of surgery. Two of 100 patients who received a single daily injection developed wound haematoma; one after an anterior resection and the other after abdominoperineal resection of the rectum. There was no statistically significant difference in the amount of blood transfused in both groups or in the fall in the postoperative haemoglobin concentration in the two groups, either when analysed on the basis of different operations or in the groups as a whole (table VI).

\section{Discussion}

One of our aims was to find whether low-molecular-weight and unfractionated heparin affected the coagulation mechanism and in-vivo platelet function to the same extent in the patients

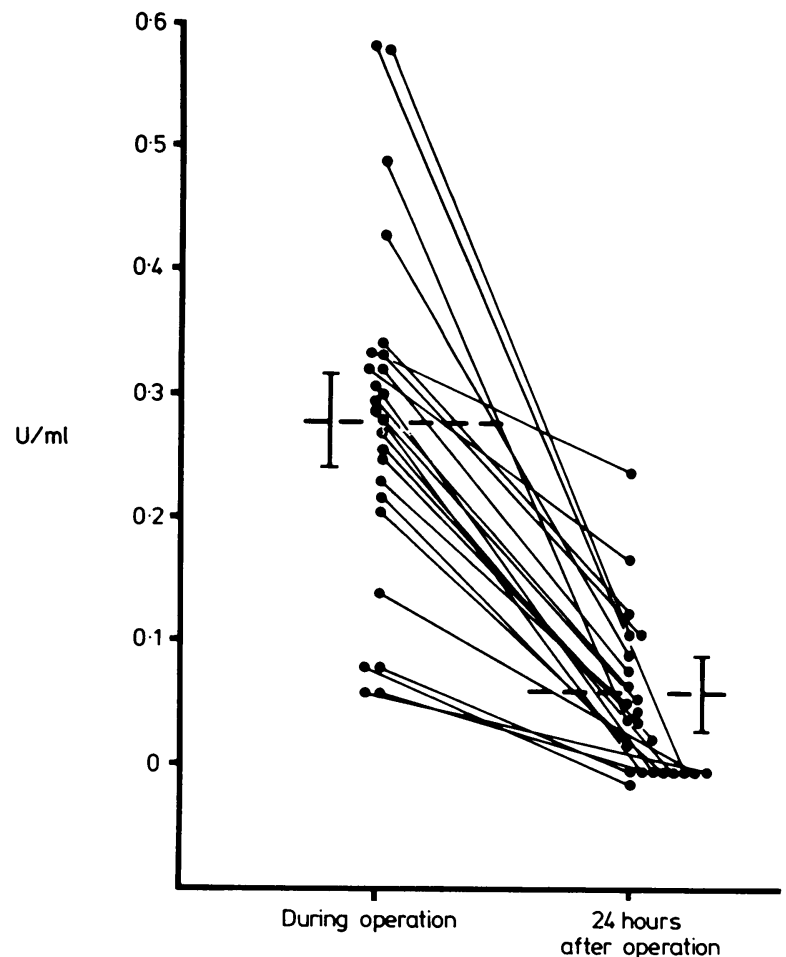

FIG 1 -Simplate bleeding time in 25 patients who received a single injection of 1850 APTT units of low-molecular-weight heparin two hours before operation. Results expressed as means + SE.

TABLE VI-Details of blood loss and haemoglobin concentration in 150 patients receiving low-molecular-weight heparin

\begin{tabular}{|c|c|c|c|c|}
\hline & \multirow{2}{*}{$\begin{array}{l}\text { No given } \\
\text { transfusions }\end{array}$} & \multirow{2}{*}{$\begin{array}{c}\text { Mean amount } \\
\text { transfused } \\
(\mathrm{ml})\end{array}$} & \multicolumn{2}{|c|}{$\begin{array}{l}\text { Mean haemoglobin } \\
\text { concentration }(\mathrm{g} \mathrm{dl})\end{array}$} \\
\hline & & & $\begin{array}{l}\text { Before } \\
\text { operation }\end{array}$ & $\begin{array}{l}\text { After } \\
\text { operation }\end{array}$ \\
\hline $\begin{array}{l}\text { Patients receiving two } \\
\text { injections daily }(n=50)\end{array}$ & 8 & $1312: 393.9$ & $14 \cdot 2: 1 \cdot 3$ & $12 \cdot 04: 1.38$ \\
\hline $\begin{array}{l}\text { Patients receiving one } \\
\text { injection daily }(\mathrm{n}=100)\end{array}$ & 17 & $1035 \cdot 2 ! 407 \cdot 1$ & $14 \cdot 9: 1.8$ & $13 \cdot 6 \pm 1 \cdot 6$ \\
\hline
\end{tabular}

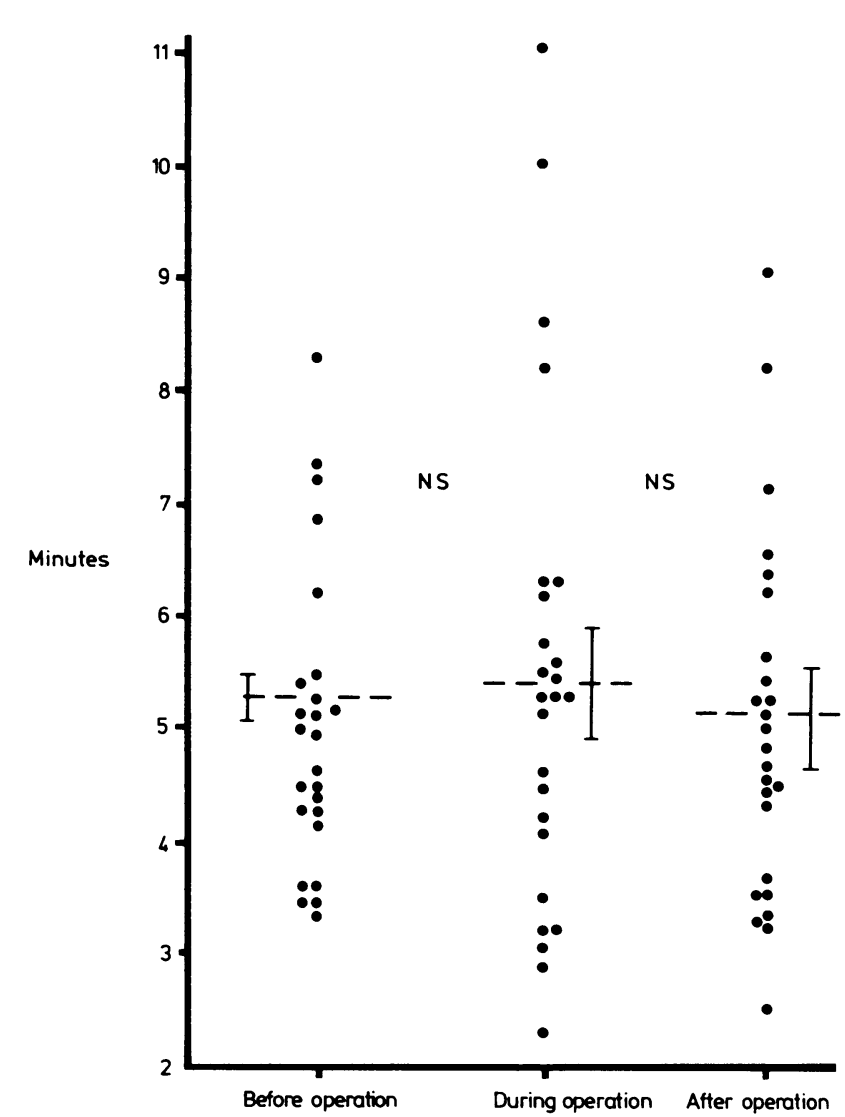

FIG 2-Plasma heparin concentration in 25 patients who received a single injection of 1850 APTT units of low-molecular-weight heparin two hours before surgery. Results expressed as means $\pm \mathrm{SE}$.

undergoing major abdominal surgery. The clotting assays ands results of platelet function tests indicated that both preparations of heparin in general produced a similar effect. Intragroup comparison, however, showed significant differences in the anti- $\frac{\mathbb{Q}}{2}$ factor Xa activity, lipoprotein lipase release, and plasma pre- $\overrightarrow{\vec{A}}$ kallikrein and thromboxane $B_{2}$ concentrations. Both heparins caused a significant increase in lipoprotein lipase compared with pretreatment values but the increase was even greater in those who received unfractionated heparin. The ability of heparin to interact with lipoprotein lipase increases with the molecular weight, suggesting that the low-molecular-weight fragment may:cause less release of free fatty acids on administration in vivos than does unfractionated heparin. ${ }^{26}$ Endothelial cells have been shown to contain heparan sulphate, platelet factor 4 , and? lipoprotein lipase in a complex bound to their cell surface. ${ }^{2}$ Unfractionated heparin being a highly charged molecule probably displaces this complex from the endothelial celli surface to a greater extent than the low-molecular-weight fraction and thus causes a greater release of lipoprotein lipase. Platelets produce prostaglandins, prostaglandin endoperoxide, and thromboxanes during aggregation and blood clotting N Therefore the high concentrations of plasma thromboxane $B_{2}{ }^{\omega}$ observed in patients receiving unfractionated heparin may reflect greater activation of platelets. This observation ise supported by the findings that low-molecular-weight heparino fraction also showed very low platelet aggregation enhancing activity. ${ }^{28} \mathrm{~A}$ significant fall in the plasma prekallikrein concentration was observed only on the first and seventh day after. operation in the patients who received unfractionated heparin $\frac{\text { Pे }}{\mathbb{Q}}$ Plasma prekallikrein concentrations are directly related to the degree of activation of factor XII. Recent studies have also shown that heparin fractions of different molecular weight and with high affinity for antithrombin differ in their ability to potentiate the inhibition of clotting factors by antithrombino III $^{29}$; inhibition of thrombin, factor IXa, and factor XIa was 
found to decrease with decreasing molecular weight. Inactivation of factor $\mathrm{Xa}$, factor XIIa, and kallikrein was potentiated by lowmolecular-weight heparin fractions that had virtually no effect on the inhibition of thrombin or factors IXa and XIa. This suggests that the antithrombotic properties of low-molecularweight heparin may be related to its ability to potentiate inactivation of serine proteinases in the initial stages of the coagulation cascade. ${ }^{29}$ Thus low-molecular-weight heparin would possess antithrombotic properties with little effect on the clotting time and, possibly, without causing bleeding.

Our second aim was to determine the efficacy of low-molecularweight heparin as a prophylactic agent against venous thromboembolism. Isotopic deep vein thrombosis was diagnosed in three of 50 patients who received two injections of 1250 units of lowmolecular-weight heparin per day. In three out of 100 patients who received a single daily injection of 1850 units of the lowmolecular-weight fraction raised counts were detected but phlebography failed to confirm the presence of thrombi in each instance. The most likely explanation for this discrepancy is that small thrombi detected by the ${ }^{125} \mathrm{I}$ fibrinogen uptake test in the muscular veins of the calf may not be shown by phlebography which often fails to visualise such veins.

None of the 150 patients who received low-molecular-weight heparin died from fatal or contributory pulmonary emboli. The other advantage of using low-molecular-weight heparin is the reduced frequency of bleeding complications after operation. Prophylaxis was discontinued owing to bleeding complications in two of 50 patients who received injections every 12 hours and in none of 100 patients receiving one daily injection. Three patients developed wound haematoma; two had received lowmolecular-weight heparin every 12 hours, while the third belonged to the group who received one injection daily.

One of the disadvantages of the low-dose heparin prophylaxis is that the drug has to be administered every eight or 12 hours, so requires considerable nursing time. A single injection of lowmolecular-weight heparin every day would not only reduce the frequency of haemorrhagic side effects but would also overcome the need for frequent drug administration and thus lead to better acceptance by the patients.

We thank the consultant surgeons of King's College Hospital for allowing us to study their patients; Choay Pharmaceuticals Ltd (Paris) for supply of the heparin; Dr Leon Poller, National Reference Laboratory for Anticoagulant Control Reagents, Manchester for supplying cephalin; and Dr J B Smith, Philadelphia, USA, for donating antisera. We also acknowledge the help of $\mathrm{Mr} \mathrm{J}$ Choay and Dr F Toulemonde in designing the studies reported in this paper. We are grateful to Miss $C$ Privett and Miss $M$ Fry for excellent technical help. The study was supported by the MRC programme grant No 973/756 and a grant from the Sir Jules Thorn Charitable Trust.

Request for reprints should be addressed to VVK.

\section{References}

${ }^{1}$ Abildgaard U. Inhibition of the thrombin-fibrinogen reaction by heparin and purified cofactor. Scand $\mathcal{F}$ Haematol $1968 ; 5: 440-5$

${ }^{2}$ Damus PS, Hick S, Rosenberg RW. Anticoagulant action of heparin. Nature $1973 ; 246: 355$.

${ }^{3}$ Osterud B, Miller-Andersson M, Abildgaard U, Prydz H. The effect of antithrombin III on the activity of the coagulation factor VII, IX and X. Thromb Haemostas $1976 ; 35: 295-301$.

4 Laurent TC, Tengblad A, Thunberg L, Hook M, Lindahal U. The molecular weight dependance of the anticoagulant activity of heparin. Biochem f 1978;175:691-701.

5 Andersson LO, Barrowcliffe TW, Holmer E, Johnson EA, Soderstrom G. Molecular weight dependency of the heparin potentiated inhibition of thrombin and activated factor X. Effect of heparin neutralisation in plasma. Thromb Res 1979;15:531-41.

6 Cifonelli JA. The relationship of molecular weight, and sulfate content and distribution to anticoagulant activity of heparin preparations. Carbohydr Res $1974 ; 37: 145-54$.

7 Johnson EA, Malloy B. The molecular weight range of mucosal heparin preparations. Carbohydr Res 1976;51:119-23.

${ }^{8}$ Andersson LO, Barrowcliffe TW, Holmer E, Johnson EA, Sims GEC. Anticoagulant properties of heparin fractionated by affinity chromato- graphy on matrix bound antithrombin III and by gel filtration. Thromb Res 1976;9:575-83.

9 Lam LH, Silbert JE, Rosenberg RD. The separation of active and inactive form of heparin. Biochem Biophys Res Commun 1976;69:570-6.

10 Johnson EA, Kirkwood TBL, Stirling Y, et al. Four heparin preparations. Anti-Xa potentiating effect of heparin after subcutaneous injection. Thromb Haemostas 1976;35:586-91.

${ }^{11}$ Lane DA, MacGregor IR, Michalski R, Kakkar VV. Anticoagulan activities of four unfractionated and fractionated heparins. Thromb Res 1978;12:257-71.

12 Barrowcliffe TW, Johnson EA, Eggleton CH, Thomas DP. Anticoagulant activities of lung and mucous heparins. Thromb Res 1978;12:27-36.

13 Barrowcliffe TW, Johnson EA, Eggleton CA, Kemball-Cook G, Thomas DP. Anticoagulant activities of high and low molecular weight heparin fractions. $B r \mathcal{F}$ Haematol $1979 ; 41: 573-83$.

14 Choay J, Lormeau JC, Petitou M, et al. Anti-Xa active heparin oligosaccharides. Thromb Res 1980;18:573-8.

${ }^{15}$ Caen J, Larrieu MJ, Samama M. L'hemostase. Paris: Expansion Scientifieque Française, 1968:133-5.

16 Yin ET, Wessler S, Butler JV. Plasma heparin: a unique practical, submicrogram-sensitive assay. $f$ Lab Clin Med 1973;81:298-310.

17 Kakkar VV, Nicolaides AN, Renney JTG, Friend JR, Clarke MD ${ }^{125}$ I-fibrinogen test adapted for routine screening. Lancet 1970;i:540-2.

18 Kakkar VV. The problems of thrombosis in the deep veins of the legs. Ann R Coll Surg Engl 1969;45:257-76.

19 Scully MF, Kakkar VV. Methods for semimicro or automated determination of thrombin, antithrombin, and heparin co-factor, using the substrate H-D-Phe-Pip-Arg-p-Nitroanilide 2-HC1. Clin Chim Acto $1977 ; 79: 595-602$.

Hardisty RM, Ingram GIC. Bleeding disorders. Oxford: 1965.

${ }^{21}$ Nilsson-Ehle P, Schotz NC. A stable radioactive substrate emulsion for assay of lipoprotein lipase. $\mathcal{F}$ Lipid Res 1976;17:536-41.

${ }^{22}$ Kluft C. Determination of prekallikrein in human plasma. Optimal conditions of activating prekallikrein. 7 Lab Clin Med 1978;91 :83-95.

${ }^{23}$ Kockum C, Frebeluis S. Rapid radioimmunoassay of human fibrinopeptide A. Removal of cross reacting fibrinogen with Bentonite. Thromb Res 1980;19:589-96.

${ }^{24}$ Levy RC, Smith JB, Silver MT, Saia J, Walnski P, Weiner L. Detection of thromboxane $\mathrm{B}_{2}$ in variant angina. Prostaglandins Med $1979 \cdot 2 \cdot 243-9$.

${ }^{25}$ Mielke CH Jr, Kaneshiro MM, Maher IA. The standardised normal Ivy bleeding time and it's prolongation by aspirin. Blood 1969;34:204-10.

${ }^{26}$ Bengtsson G, Olivecroma T, Hook M, Riesenfeld J, Linahl U. Interaction of lipoprotein lipase with native and modified heparin-like polysacchardies. Biochem $\mathcal{F}$ (in press)

${ }^{27}$ Buonassisi V. Sulphated mucopolysaccharide synthesis and secretion in endothelial cell culture. Exp Cell Res 1973;76:363-78

${ }^{28}$ Holmer E, Lindahl U, Backstrom G, et al. Anticoagulant activities and effects on platelets of a heparin fragment with high affinity for antithrombin. Thromb Res 1980;18:861-9.

${ }^{29}$ Holmer E, Kirchi K, Soderstrom G. The molecular weight dependence of the rate enhancing effect of heparin on the inhibition of thrombin, Factor Xa, Factor IXa, Factor XIIa and kallikrein by antithrombin. Biochem $\mathcal{F} 1981 ; 193: 395-400$.

(Accepted 21 October 1981)

MEDICINES TEMPERATE-If the world be composed of extremes, then it acts by extremes, for as the man is, so is his work: therefore it is impossible that any medicine can be temperate, but may be reduced to heat, cold, dryness, or moisture, and must operate (I mean such as operate by manifest quality) by one of these, because there is no other to operate by, and that there should be such a temperate mixture, so exquisitely of these qualities in any medicine, that one of them should not manifestly excel the other, I doubt it is a system too rare to find. Thus then I conclude the matter to be, those Medicines are called temperate (not because they have excess of temperature at all in them) which can neither be said, to heat nor cool so much as will amount to the first degree of excess, for daily experience witnesses that they being added to medicines, change not their qualities, they make them neither hotter nor colder.

They are used in such diseases where there is no manifest distemper of the first qualities, viz heat and cold, for example; In obstruction of the bowels, where cold medicines might make the obstruction greater, and hot medicines cause a fever. In fevers of flegm, where the cause is cold and moist, and the effect hot and dry; in such, use temperate medicines which may neither encrease the fever by their heat, nor condensate the flegm by their coldness. Besides, because contraries are taken away by their contraries, and every like maintained by its like, they are of great use, to preserve the constitution of the body temperate, and the body itself in strength and vigour, and may be used without danger, or fear of danger, by considering which part of the body is weak, and using such temperate medicines as are appropriated to that part. (Nicholas Culpeper (1616-54) The Complete Herbal, 1850.) 